Research Article

\title{
Studies on Effect of Addition of Date Pit Powder and Soy Protein Isolate on Physicochemical Properties of Date Bars
}

\author{
Lala Rukh¹, Muhammad Nadeem ${ }^{1}$, Tusneem Kausar ${ }^{1}$, Mian Anjum Murtaza ${ }^{1}$, Muhammad Luqman ${ }^{2 *}$, \\ Muhammad Bilal Shahid ${ }^{1}$ and Amal Shaukat ${ }^{3}$
}

${ }^{1}$ Institute of Food Science and Nutrition, University of Sargodha, Sargodha, Pakistan; ${ }^{2}$ Department of Agricultural Extension, College of Agriculture, University of Sargodha, Sargodha, Pakistan; ${ }^{3}$ Department of Food Science and Technology, University of Central Punjab, Lahore- Pakistan

Abstract | Current study was aimed to formulate a nutritious snack bar by incorporating date pit powder (by
product) and soy protein isolate in date paste. Date bars were formulated after ingredients optimization and
were analyzed for physico-chemical, in-vitro starch and protein digestibility, antioxidants and microbial count.
Results showed that date bars are rich source of protein, fiber, carbohydrates and fat with good digestibility
properties. Date pit powder and soy protein isolate incorporation enhanced the total antioxidants and DPPH
activity in soy date bars however, decreasing trend was observed in total antioxidants and inhibition of DPPH
radical activity during 90 days of storage. Based on the results, it has been suggested that date bars may
be considered as a source to meet the energy requirements of health-conscious consumers. Moreover, date
pit powder and soy protein isolate can be used as nutraceutical in different functional foods as a valuable
nourishment source for target population.
Received $\mid$ March 11, 2021; Accepted | June 24, 2021; Published | August 17, 2021
*Correspondence | Muhammad Luqman, University of Sargodha, Sargodha, Pakistan; Email: muhammad.luqman@uos.edu.pk
Citation $\mid$ Rukh, L., M. Nadeem, T. Kausar, M.A. Murtaza, M. Luqman, M.B. Shahid and A. Shaukat. 2021. Studies on effect of addition of date
pit powder and soy protein isolate on physicochemical properties of date bars. Sarbad Journal of Agriculture, 37(4):1134-1143.
DOI $\mid$ https://dx.doi.org/10.17582/journal.sja/2021/37.4.1134.1143
Keywords | Date pit powder, DPPH, IVPD, IVSD, Soy protein isolate, Total plate count

\section{Introduction}

$\mathrm{F}$ ood bars are snack food containing cereals and nuts and are usually consumed as breakfast food. It is popular in different parts of the world like North America, South America, Europe and Australia. Food bars are usually similar to fruits in composition but differ in shape (Parn et al., 2015). Different techniques have been developed for different food bars production and to increase the market value (Aparecida et al., 2016).

Due to the functional and nutritional value and development cost of byproducts and agro-industrial use, food waste has been involved as ingredients in food bars preparation (Marques et al., 2015). Cereal bars that are high in isoflavones and soy protein were helpful in controlling dyslipidemia, when become part of daily diet. Consumers believed that food bars have significant nutritious effects on health because of a suitable balance between calories, fat, protein, minerals, whole grains, vitamins, and fiber (Ryland et al., 2010). Date fruits have always played a significant role in improving the economic and social health of people in a society. They are an excellent source of phenolic compounds with high antioxidant capacity. It also has strong carotenoids, anthocyanins, flavonoids and phenolic contents (Zineb et al., 2012). Date pit after conversion into powder form is used in different medications like lesions, wounds, 
inflammation reliever, a great medicine for stomach problems, laxative, and recommended for gonorrhea and asthma, good source of nutrients. Polyphenols are the main compounds in date seeds and have shown fruitful outcomes, which can eventually contribute to the sustainability and worth addition in the date processing industry (Sirisena et al., 2015). Date pit oil usage on the skin has shielding effects from damages (Dammak et al., 2007).

Soybean (Glycine max) consumption in Asian countries is very common since ancient times. Daily consumption of soy foods in our diet has potential health benefits and prevents us from the risk of chronic cardiovascular and liver diseases. Soy food consumption reduced menace of diverse kinds of cancers like breast and prostate and provide relief to females in menopausal system and good for bone health (Kurosu, 2011).

Cereal bars made with incorporation of dried fruits are the wholesome alternative of fresh fruits and vegetables that were introduced in the last decade, when consumer's interest increased in diets and health (Bower and Whitten, 2000). This study was planned to develop date bars by utilizing agro-industrial byproducts such as date pit powder and soy protein isolate and its physicochemical, phenolic contents and shelf life stability assessment was carried out.

\section{Materials and Methods}

\section{Procurement of raw materials}

Raw materials required in the preparation of soy date bars like dates, roasted corn flour, cardamom, salt and soy protein isolates were purchased from local market at Sargodha. Commercial date variety Dhakki was selected for the date bars preparation. Pits of dates were washed, crushed and ground in grinder to convert into powder form. Chemicals (Fluka Chemicals Co. (Buchs, Switzerland) required for analysis of raw materials were purchased from local market.

\section{Preparation of soy date bars}

Soy date bars were prepared according to the method of Munir et al. (2016) with some modifications. After the preparation of raw material, roasted corn flour, salt, cardamom, date pit powder and soy protein isolates were added in date paste and made firmed dough. After preparation of dough, sheeting and cutting of dough was done into bars of $2.5 \mathrm{~cm}$ width,
$1 \mathrm{~cm}$ thickness and $7 \mathrm{~cm}$ length with the assistance of cutter. After cutting, bars were transferred to oven for 20 minutes at $180{ }^{\circ} \mathrm{C}$ for baking. After cooling each bar of $25 \pm 1 \mathrm{~g}$ was packed separately in Aluminum foil.

\section{Adjustment of ingredients involved in date bar preparation}

After selection and preparation of ingredients of date bars, the levels of two ingredients i.e. date pit powder and soy protein isolate were optimized by using response surface methodology. The minimum and maximum levels of variables i.e. date pit powder and soy protein isolate were selected by preliminary trials. Following treatment plan was finalized; $\mathrm{T}_{0}$ (Control Treatment); $\mathrm{T}_{1}$ containing soy protein isolates $(16.44 \mathrm{~g}) ; \mathrm{T}_{2}$ containing date pit powder $(10.35 \mathrm{~g}) ; \mathrm{T}_{3}$ contain both soy protein isolate $(16.44 \mathrm{~g})$ and date pit powder (10.35g).

\section{Color measurement}

The color of bars was evaluated using Neotech color meter by employing procedure as described by Bano et al. (2016). The color meter was standardized by utilizing standard colors (151 CTn for light and 54 CTn for dark). Color of bars was noted by placing the bars under the photocell.

\section{Proximate composition}

The proximate composition such as ash, moisture, crude protein, crude fiber and crude fat of soya date bars was determined and results were described on the basis of dry matter (AACC, 2000).

\section{In-vitro digestibility of protein}

In-vitro digestibility of protein in soy date bars was measured by the method of pepsin digestibility method as described by Chen et al. (2015).

In a test tube, $200 \mathrm{mg}$ sample of powdered soya date bar material was added in $35 \mathrm{~mL}$ solution of pepsin and incubated for two hours at $37^{\circ} \mathrm{C}$ temperature with mild shaking. Then centrifugation was done at $12,000 \mathrm{~g}$ at $40^{\circ} \mathrm{C}$ for $15 \mathrm{~min}$. The filtrate obtained was adjourned in $0.035 \mathrm{M} \mathrm{HCl}(10 \mathrm{~mL})$ and recentrifuged. The remaining filtrate was then collected and dried at $40^{\circ} \mathrm{C}$ temperature for overnight. The quantity of nitrogen available in filtrate was measured by using the method of micro-Kjeldahl apparatus. Blank reading was taken without the addition of sample. 
radical 2, 2-diphenyl-1-picryl hydrazyl (DPPH) and the results were demonstrated as of free radical scavenging activity. $1 \mathrm{~mL}$ of water soluble extract (WSE) were taken and then $2 \mathrm{~mL}$ of DPPH $(60$ $\mu \mathrm{m}$ in ethanol) solution was added. Then incubation was done for $30 \mathrm{~min}$ in the dark. Spectrophotometer was used to measure the absorbance at $517 \mathrm{~nm}$. The preparation of control (ethanol) was also done using the same method. Spectrophotometer was calibrated by running blank (distilled water). Reduction in absorbance was calculated in the samples. The $\mathrm{mmol} / \mathrm{g}$ equivalent of ascorbic acid was used to express the DPPH radical scavenging activity.

\section{Total plate count}

Date bars samples were analyzed for microbial count to check shelf stability during 90 days of storage. Total plate count analysis was performed as described in method no. 42-11 of AACC (1999). 10 gram of date bar sample was thoroughly mixed in a sterile blender jug containing $90 \mathrm{ml}$ of phosphate buffer solution. One $\mathrm{ml}$ of suspension with $10^{-1}$ dilution is transferred with a sterile pipette to solution of $9 \mathrm{ml}$ of phosphate buffer to obtain $10^{-2}$ dilution. Dilution was carried out to $10^{-3}, 10^{-4}$, agitated to suspend material that might be settled out and transported $1 \mathrm{ml}$ of every bottle into correctly marked and duplicate petri dishes. $12-15 \mathrm{ml}$ of plate count agar was added to petri dish cooled to $45^{\circ} \mathrm{C}$ within 15 minutes of original dilution, immediately mix the agar medium and sample dilution for uniformly distribution. Agar medium in plates was allowed to solidify and then incubated at $35 \mathrm{C}^{\circ}$ for $48 \pm 2$ hour by keeping it inverted. Duplicate plates were counted after incubation period plates having 25300 colonies.

\section{Statistical analysis}

All the results were reported as means of three replicates and analyzed statistically by utilizing ANOVA Test at alpha 0.05 . The difference in means was assessed by LSD test through Statistix 8.1 software (Steel, 1997).

\section{Results and Discussion}

\section{Color of date bars}

The research findings described that the values of color are remarkably differed among different treatments. The color values of treatments ranged from $116.55 \pm 1.2$ to $121.73 \pm 1.27 \mathrm{CTn}$ having the maximum value in control treatment $\left(\mathrm{T}_{0}\right)$ while minimum value was noted for $\mathrm{T}_{2}$ treatment. It is clear

\section{DPPH activity}

The modified DPPH method described previously (Szydłowska et al., 2010) was used for determination of the antioxidant capacity with the stable free 
from the findings that when date pit powder increased in the treatments, the color values gradually decreased (Table 1). Decreased color values indicate dark color. Storage time had significant effect on the color of date bars. During the storage period mean values of color ranged from $122.43 \pm 0.95$ to $117.38 \pm 1.3 \mathrm{CT}$ for 0 to 90 days respectively. During storage period the color change in various treatments are in conformity with the findings of Sunita and Chauhan (2008) who described that color altered significantly in drumdried papaya-cereal flakes from 54.73-30.30 during 60 days storage period.

\section{Proximate analysis of soya date bars}

The statistical analysis indicated that date bars treatments with different concentration of soy protein isolates and date pit powder at storage period of 90 days at ambient temperature differs significantly in proximate composition among different treatments and storage period.

\section{Moisture content of soya date bars}

The mean values of moisture in four treatments of date bars including different quantities of soy protein isolate and date pit powder ranged from 8.14 to $5.36 \%$ containing the maximum score for $\mathrm{T}_{0}(8.14 \%$ and the minimum score in case of $\mathrm{T}_{3}(5.36 \%)$. There was reduction in moisture content with enhancing date pit powder concentrations and soy protein isolate in treatments as these powder contain less moisture content and decreased overall moisture content in soya date bars. Moisture content in soya date bars possibly decreased because of evaporation of water from the date bars as a result of temperature (Table 2). The variation of moisture during storage for numerous treatments is in conformity with the Kamran et al. (2008) who described that moisture content changed significantly in slices of mango from $6.75-5.69 \%$ during storage of 6 months.
Crude protein content of date bars

Treatment effect has significant impact on amount of protein in date bars. The protein among treatments ranged from 3.46 to $13.54 \%$ (Table 3 ), containing the maximum amount in $\mathrm{T}_{1}(14.06 \%)$ and the minimum in $\mathrm{T}_{0}(3.46 \%)$. The results indicated that when soy protein isolate incorporation increased in treatments, the protein contents increased. In treatment $T_{2}$ (3.75\%) minor protein content increase was observed as date pit powder contains less quantity of protein. Treatment $\mathrm{T}_{3}$ contained appreciable amount of protein $(13.55 \%)$ as it contained soya protein isolate and date pits powder. The results obtained are in conformity with the findings of Abbas et al. (2016) who studied that there was gradual increase in the protein contents of food bars supplemented with defatted sesame seed flour. The protein content of date bars changed nonsignificantly during storage and the results obtained are in close agreement with the findings of Rokhshana et al. (2007) who studied that protein contents in legume and vegetable-based soup powder changed non-significantly during storage of 6 months.

\section{Ash content of date bar}

The ash content of date bars among different treatments differed significantly (Table 4). The ash content in treatments ranged from 1.47 to $1.54 \%$ containing the maximum amount in $\mathrm{T}_{2}$ (1.54\%) and minimum in $\mathrm{T}_{0}(1.47 \%)$. When date pit powder concentration increased in treatment, ash content gradually increased. Treatment $\mathrm{T}_{2}(1.53 \%)$ has maximum ash content due to date pit powder, however $\mathrm{T}_{3}$ also contain good amount of ash content (1.51\%). Ash content remained unchanged during 90 days of storage time. Raza et al. (2019) concluded that ash content of dried date powder procured from different cultivars remained unchanged after 2 months of storage period.

Table 1: Color values (CTn) of date bars during storage.

\begin{tabular}{llllll} 
Treatment & \multicolumn{2}{c}{ Storage (Days) } & Mean \\
& 0 & 30 & 60 & 90 & $121.73 \pm 1.27^{\mathrm{a}}$ \\
$\mathrm{T}_{0}$ & $124.45 \pm 1.45^{\mathrm{a}}$ & $121.72 \pm 1.31^{\mathrm{cd}}$ & $121.24 \pm 1.07^{\mathrm{b}-\mathrm{e}}$ & $119.53 \pm 1.26^{\mathrm{e}-\mathrm{h}}$ & $120.58 \pm 1.1^{\mathrm{b}}$ \\
$\mathrm{T}_{1}$ & $122.58 \pm 1.67^{\mathrm{ab}}$ & $120.98 \pm 1.35^{\mathrm{b}-\mathrm{f}}$ & $119.67 \pm 1.4^{\mathrm{d}-\mathrm{h}}$ & $118.08 \pm 1.3^{\mathrm{f}-\mathrm{h}}$ & $116.75 \pm 1.2^{\mathrm{c}}$ \\
$\mathrm{T}_{2}$ & $120.42 \pm 1.25^{\mathrm{c}-\mathrm{g}}$ & $117.68 \pm 1.5^{\mathrm{i}-\mathrm{k}}$ & $116.55 \pm 1.4^{\mathrm{jk}}$ & $114.49 \pm 1.3^{\mathrm{k}}$ & $118.07 \pm 1.44^{\mathrm{c}}$ \\
$\mathrm{T}_{3}$ & $122.08 \pm 1.33^{\mathrm{bc}}$ & $118.75 \pm 2.05^{\mathrm{g}-\mathrm{I}}$ & $117.68 \pm 1.06^{\mathrm{h}-\mathrm{j}}$ & $115.42 \pm 1.41^{\mathrm{k}}$ & \\
Mean & $122.43 \pm 0.95^{\mathrm{a}}$ & $119.54 \pm 1.48^{\mathrm{b}}$ & $118.78 \pm 1.07^{\mathrm{b}}$ & $117.38 \pm 1.3^{\mathrm{c}}$ &
\end{tabular}

LSD value for treatment and storage $=0.7794 ;$ LSD value for interaction (Treatment $\times$ storage) $=2.1320 ; T_{0}:$ (control) without date pits powder and soy protein isolate; $T_{1}$ : having soy protein isolates; $T_{2}$ : having date pits powder; $T_{3}$ : having date pits powder + soy protein isolates.

December 2021 | Volume 37 | Issue 4 | Page 1137 
Table 2: Moisture content (\%) of date bars during storage.

$\begin{array}{llllll}\text { Treatment } & \text { Days } & & & & \text { Mean } \\ & 0 & 30 & 60 & 90 & \\ \mathrm{~T}_{0} & 8.42 \pm 0.08^{\mathrm{a}} & 8.22 \pm 0.29^{\mathrm{ab}} & 8.04 \pm 0.16^{\mathrm{ab}} & 7.88 \pm 0.33^{\mathrm{b}} & 8.14 \pm 0.22^{\mathrm{a}} \\ \mathrm{T}_{1} & 6.47 \pm 0.20^{\mathrm{ef}} & 6.30 \pm 0.25^{\mathrm{fg}} & 6.12 \pm 0.18^{\mathrm{fg}} & 5.92 \pm 0.32^{\mathrm{gh}} & 6.20 \pm 0.24^{\mathrm{c}} \\ \mathrm{T}_{2} & 7.38 \pm 0.11^{\mathrm{c}} & 7.22 \pm 0.12^{\mathrm{cd}} & 7.05 \pm 0.34^{\mathrm{cd}} & 6.88 \pm 0.29^{\mathrm{de}} & 7.13 \pm 0.22^{\mathrm{b}} \\ \mathrm{T}_{3} & 5.58 \pm 0.02^{\mathrm{hi}} & 5.46 \pm 0.09^{\mathrm{j}} & 5.29 \pm 0.01^{\mathrm{j}} & 5.10 \pm 0.07^{\mathrm{j}} & 5.36 \pm 0.05^{\mathrm{d}} \\ \text { Mean } & 6.96 \pm 0.10^{\mathrm{a}} & 6.80 \pm 0.19^{\mathrm{b}} & 6.62 \pm 0.17^{\mathrm{c}} & 6.44 \pm 0.25^{\mathrm{d}} & \end{array}$

$L S D$ value for treatment $=0.2283 ; L S D$ value for storage $=0.1529 ; L S D$ value for interaction (Treatment $\times$ storage $)=0.4182 ; T_{0}:$ (control) without date pits powder and soy protein isolate; $T_{1}$ : having soy protein isolates; $T_{2}$ : having date pits powder; $T_{3}$ : having date pits powder + soy protein isolates.

Table 3: Protein content (\%) of date bars during storage.

\begin{tabular}{|c|c|c|c|c|c|}
\hline \multirow[t]{2}{*}{ Treatment } & \multicolumn{4}{|l|}{ Days } & \multirow[t]{2}{*}{ Mean } \\
\hline & 0 & 30 & 60 & 90 & \\
\hline $\mathrm{T}_{0}$ & $3.48 \pm 0.28$ & $3.47 \pm 0.28$ & $3.46 \pm 0.23$ & $3.44 \pm 0.23$ & $3.46 \pm 0.25^{c}$ \\
\hline $\mathrm{T}_{1}$ & $14.08 \pm 0.31$ & $14.08 \pm 0.33$ & $14.06 \pm 0.32$ & $14.05 \pm 0.30$ & $14.06 \pm 0.32^{\mathrm{a}}$ \\
\hline $\mathrm{T}_{2}$ & $3.75 \pm 0.15$ & $3.74 \pm 0.24$ & $3.73 \pm 0.36$ & $3.73 \pm 0.36$ & $3.74 \pm 0.28^{c}$ \\
\hline $\mathrm{T}_{3}$ & $13.55 \pm 0.03$ & $13.55 \pm 0.02$ & $13.55 \pm 0.06$ & $13.52 \pm 0.25$ & $13.54 \pm 0.09^{b}$ \\
\hline Mean & $8.72 \pm 0.19$ & $8.71 \pm 0.22$ & $8.70 \pm 0.24$ & $8.68 \pm 0.29$ & \\
\hline
\end{tabular}

$L S D$ value for treatment $=0.2757 ; T_{0^{;}}$(control) without date pits powder and soy protein isolate; $T_{1}$ : having soy protein isolates; $T_{2}$ : having date pits powder; $T_{3}$ : having date pits powder + soy protein isolates.

Table 4: Ash content (\%) of date bars during storage.

\begin{tabular}{llllll} 
Treatment & Days & & & \multicolumn{2}{c}{ Mean } \\
& $\mathbf{0}$ & $\mathbf{3 0}$ & $\mathbf{6 0}$ & $\mathbf{9 0}$ & \\
$\mathrm{T}_{0}$ & $1.47 \pm 0.10$ & $1.46 \pm 0.07$ & $1.47 \pm 0.18$ & $1.46 \pm 0.18$ & $1.47 \pm 0.13^{\mathrm{c}}$ \\
$\mathrm{T}_{1}$ & $1.48 \pm 0.27$ & $1.48 \pm 0.23$ & $1.48 \pm 0.23$ & $1.47 \pm 0.23$ & $1.48 \pm 0.24^{\mathrm{bc}}$ \\
$\mathrm{T}_{2}$ & $1.53 \pm 0.21$ & $1.55 \pm 0.10$ & $1.54 \pm 0.10$ & $1.53 \pm 0.10$ & $1.54 \pm 0.12^{\mathrm{a}}$ \\
$\mathrm{T}_{3}$ & $1.51 \pm 0.07$ & $1.49 \pm 0.06$ & $1.51 \pm 0.06$ & $1.50 \pm 0.06$ & $1.50 \pm 0.06^{\mathrm{b}}$ \\
Mean & $1.49 \pm 0.16$ & $1.50 \pm 0.11$ & $1.49 \pm 0.14$ & $1.49 \pm 0.14$ &
\end{tabular}

$L S D$ value for treatment $=0.0305 ; T_{0}:$ (control) without date pits powder and soy protein isolate; $T_{1}:$ having soy protein isolates; $T_{2}:$ having date pits powder; $T_{3}$ : having date pits powder + soy protein isolates.

Table 5: Fat content (\%) of date bars during storage.

$\begin{array}{llllll}\text { Treatment } & \text { Days } & & & & \text { Mean } \\ & \mathbf{0} & \mathbf{3 0} & \mathbf{6 0} & \mathbf{9 0} & \\ \mathrm{T}_{0} & 0.85 \pm 0.06 & 0.85 \pm 0.05 & 0.84 \pm 0.15 & 0.84 \pm 0.15 & 0.85 \pm 0.10^{\mathrm{d}} \\ \mathrm{T}_{1} & 1.05 \pm 0.10 & 1.04 \pm 0.10 & 1.02 \pm 0.09 & 1.02 \pm 0.09 & 1.03 \pm 0.10^{\mathrm{c}} \\ \mathrm{T}_{2} & 1.21 \pm 0.13 & 1.22 \pm 0.13 & 1.20 \pm 0.13 & 1.20 \pm 0.13 & 1.20 \pm 0.13^{\mathrm{b}} \\ \mathrm{T}_{3} & 1.31 \pm 0.21 & 1.30 \pm 0.20 & 1.29 \pm 0.20 & 1.28 \pm 0.20 & 1.29 \pm 0.20^{\mathrm{a}} \\ \text { Mean } & 1.10 \pm 0.13 & 1.10 \pm 0.12 & 1.09 \pm 0.14 & 1.08 \pm 0.14 & \end{array}$

$L S D$ value for treatment $=0.0484 ; T_{\sigma}$ (control) without date pits powder and soy protein isolate; $T_{r} \cdot$ having soy protein isolates; $T_{2}$ : having date pits powder; $T_{3}$ : having date pits powder + soy protein isolates.

Crude fat content of date bars

Crude fat content of date bar treatments ranged from 1.29 to $0.85 \%$ containing the maximum amount in $\mathrm{T}_{3}$ and the minimum in $\mathrm{T}_{0}$ (Table 5). Date bars $\left(\mathrm{T}_{2}\right.$ and $\mathrm{T}_{3}$ ) have high fat contents because of date pit powder incorporation in both treatments. The results showed that when concentrations of date pit powder increased, fat contents gradually increased. Fat content was ranged from 1.10-1.08\% during 90 days storage. Non-significant variations was observed in fat content of bars during storage. Addition of date pit powder and soy protein isolate cause significant 
enhancement in crude fat content. These results had close agreement with the findings of Nadeem et al. (2012) who described that vetch protein isolate and whey protein concentrate addition causes significant enhancement in crude fat content of date bars.

\section{Crude fiber content of date bars}

The fiber content in treatment ranged from 3.55 to 8.91\% having the lowest in $\mathrm{T}_{1}$ and the highest value in $\mathrm{T}_{2}$ (Table 6). The findings demonstrate that when date pit powder increased in treatment, fiber contents gradually increased. Date powder contains significant amount of fiber. Amount of fiber in treatment $T_{1}$ decreased might be due to negligible amount of fiber in soya protein isolate. Fiber content of date bars changed non-significantly during storage. The results obtained are in accordance with the findings of Munshi et al. (2020) who also found non-significant differences in fiber contents of nutrient bars during storage. Iqbal (2003) performed a research on different shortening effects on the cookies quality and observed that fiber content reduced non-significantly from $0.26-0.15 \%$ after 45 days of storage.

\section{In-vitro protein digestibility (IVPD) of date bar}

The IVPD at ambient temperature ranged from 76.75 to $79.56 \%$ having the minimum digestibility in $\mathrm{T}_{2}$ and the maximum in $\mathrm{T}_{1}$ (Table 7 ). The results demonstrated that when amount of soy protein isolate increased in treatment, IVPD gradually increased. Soya protein has good digestibility and is used in many formulations. IVPD of date-bar sample has significant effects of storage. At start of study IVPD was observed to be $79.95 \%$ but after 90 days it was decreased to $75.86 \%$. During storage period various treatments for IVPD change is in conformity with the findings of Pinto et al. (2005), who reported significant storage impacts on IVPD in all four treatments of isolates of soy protein and flours of defatted soy during 6 months storage at $42^{\circ} \mathrm{C}$.

\section{In-vitro starch digestibility (IVSD) of date bars}

The mean values for IVSD of treatments ranged from 358.81 to $376.91 \mathrm{mg} / \mathrm{g}$ dry sample containing the maximum in $\mathrm{T}_{0}$ and the minimum in $\mathrm{T}_{1}$ (Table 8). The results demonstrated that with the increase in soy protein isolate and date pit powder in treatment, IVSD decreased gradually. IVSD of date bars during storage changed non-significantly. The mean values during storage ranged from 362.97 to $374.56 \mathrm{mg} / \mathrm{g}$ at 0 and 90 days respectively. The results of IVSD in various treatments are in close conformity with the findings of Rendon et al. (2002) who described non-significant storage effect on IVSD in all four treatments of nixtamal, masa, and tortilla during 4 days storage at room temperature.

Table 6: Fiber content (\%) of date bars during storage.

\begin{tabular}{llllll} 
Treatment & Days & & \multicolumn{2}{c}{ Mean } & \\
& $\mathbf{0}$ & $\mathbf{3 0}$ & $\mathbf{6 0}$ & $\mathbf{9 0}$ & \\
$\mathrm{T}_{0}$ & $4.02 \pm 0.07$ & $4.02 \pm 0.08$ & $4.01 \pm 0.10$ & $4.01 \pm 0.10$ & $4.01 \pm 0.09^{\mathrm{c}}$ \\
$\mathrm{T}_{1}$ & $3.54 \pm 0.10$ & $3.55 \pm 0.16$ & $3.56 \pm 0.15$ & $3.55 \pm 0.15$ & $3.55 \pm 0.14^{\mathrm{d}}$ \\
$\mathrm{T}_{2}$ & $8.93 \pm 0.12$ & $8.92 \pm 0.12$ & $8.90 \pm 0.12$ & $8.89 \pm 0.12$ & $8.91 \pm 0.12^{\mathrm{a}}$ \\
$\mathrm{T}_{3}$ & $7.95 \pm 0.04$ & $7.93 \pm 0.06$ & $7.93 \pm 0.05$ & $7.92 \pm 0.05$ & $7.93 \pm 0.05^{\mathrm{b}}$ \\
Mean & $6.11 \pm 0.08$ & $6.11 \pm 0.10$ & $6.10 \pm 0.10$ & $6.09 \pm 0.10$ &
\end{tabular}

$L S D$ value for treatment $=0.0750 ; T_{\sigma}$ (control) without date pits powder and soy protein isolate; $T_{1}$ : having soy protein isolates; $T_{2}$ : having date pits powder; $T_{3}$ : having date pits powder + soy protein isolates.

Table 7: IVPD (\%) of date bars during storage.

\begin{tabular}{|c|c|c|c|c|c|}
\hline \multirow[t]{2}{*}{ Treatment } & \multicolumn{4}{|l|}{ Days } & \multirow[t]{2}{*}{ Mean } \\
\hline & 0 & 30 & 60 & 90 & \\
\hline $\mathrm{T}_{0}$ & $79.07 \pm 0.32^{\mathrm{a}-\mathrm{c}}$ & $77.43 \pm 1.19^{a-d}$ & $76.43 \pm 1.19^{\mathrm{b}-\mathrm{d}}$ & $75.43 \pm 1.19^{\mathrm{cd}}$ & $77.09 \pm 0.97^{b}$ \\
\hline $\mathrm{T}_{1}$ & $81.14 \pm 1.41^{\mathrm{a}}$ & $80.48 \pm 0.85^{\mathrm{a}}$ & $78.81 \pm 0.75^{\mathrm{a}-\mathrm{c}}$ & $77.81 \pm 1.35^{\mathrm{a}-\mathrm{c}}$ & $79.56 \pm 1.09^{a}$ \\
\hline $\mathrm{T}_{2}$ & $75.83 \pm 0.89^{\mathrm{ab}}$ & $74.50 \pm 1.33^{\mathrm{a}-\mathrm{d}}$ & $73.83 \pm 1.86^{\mathrm{cd}}$ & $72.83 \pm 1.86^{\mathrm{d}}$ & $76.75 \pm 1.48^{b}$ \\
\hline $\mathrm{T}_{3}$ & $79.72 \pm 1.40^{\mathrm{ab}}$ & $78.05 \pm 1.52^{\mathrm{a}-\mathrm{c}}$ & $76.39 \pm 1.32^{\mathrm{b}-\mathrm{d}}$ & $76.39 \pm 0.32^{\mathrm{b}-\mathrm{d}}$ & $77.64 \pm 1.14^{b}$ \\
\hline Mean & $79.95 \pm 1.00^{\mathrm{a}}$ & $78.36 \pm 1.22^{\mathrm{b}}$ & $76.86 \pm 1.28^{c}$ & $75.86 \pm 1.18^{c}$ & \\
\hline
\end{tabular}

LSD value for treatment and storage $=1.3819 ;$ LSD value for interaction (Treatment $\times$ storage) $=3.7804 ; T_{0}$ : (control) without date pits powder and soy protein isolate; $T_{1}$ : having soy protein isolates; $T_{2}$ : having date pits powder; $T_{3}$ : having date pits powder + soy protein isolates.

December 2021 | Volume 37 | Issue 4 | Page 1139 
Table 8: IVSD (unit on dry weight basis) of date bars during storage.

$\begin{array}{llllll}\text { Treatment } & \text { Days } & & & \text { Mean } \\ & \mathbf{0} & \mathbf{3 0} & \mathbf{6 0} & \mathbf{9 0} & \\ \mathrm{T}_{0} & 375.41 \pm 0.85^{\mathrm{a}} & 376.41 \pm 0.85^{\mathrm{a}} & 378.07 \pm 0.76^{\mathrm{a}} & 377.74 \pm 1.4^{\mathrm{a}} & 376.91 \pm 0.96^{\mathrm{a}} \\ \mathrm{T}_{1} & 355.40 \pm 0.58^{\mathrm{c}} & 358.40 \pm 1.43^{\mathrm{c}} & 359.06 \pm 1.94^{\mathrm{c}} & 362.40 \pm 2.21^{\mathrm{bc}} & 358.81 \pm 1.54^{\mathrm{b}} \\ \mathrm{T}_{2} & 362.80 \pm 0.92^{\mathrm{bc}} & 373.13 \pm 2.02^{\mathrm{ab}} & 379.46 \pm 0.51^{\mathrm{a}} & 376.46 \pm 13.65^{\mathrm{a}} & 372.96 \pm 4.27^{\mathrm{a}} \\ \mathrm{T}_{3} & 358.29 \pm 0.84^{\mathrm{a}} & 376.29 \pm 2.79^{\mathrm{a}} & 377.62 \pm 2.92^{\mathrm{a}} & 381.62 \pm 1.19^{\mathrm{c}} & 373.46 \pm 1.93^{\mathrm{a}} \\ \text { Mean } & 362.97 \pm 0.79 & 371.06 \pm 1.77 & 373.56 \pm 1.53 & 374.56 \pm 4.61 & \end{array}$

$L S D$ value for treatment and storage $=4.1491 ; L S D$ value for interaction (Treatment $\times$ storage) $=11.350 ; T_{0}$ : (control) without date pits powder and soy protein isolate; $T_{1}$ : having soy protein isolates; $T_{2}$ : having date pits powder; $T_{3}$ : having date pits powder + soy protein isolates.

Table 9: Total plate count $\left(\log _{10} C F U / g\right)$ of date bars during storage.

$\begin{array}{llllll}\text { Treatment } & \text { Storage (Days) } & & & & \\ & \mathbf{0} & \mathbf{3 0} & \mathbf{6 0} & \mathbf{9 0} & \\ \mathrm{T}_{0} & 1.95 \pm 0.24^{\mathrm{e}-\mathrm{g}} & 2.01 \pm 0.22^{\mathrm{c}-\mathrm{f}} & 2.05 \pm 0.23^{\mathrm{b}-\mathrm{e}} & 2.10 \pm 0.22^{\mathrm{a}-\mathrm{e}} & 2.02 \pm 0.24^{\mathrm{b}} \\ \mathrm{T}_{1} & 2.14 \pm 0.19^{\mathrm{a}-\mathrm{d}} & 2.16 \pm 0.08^{\mathrm{a}-\mathrm{c}} & 2.19 \pm 0.20^{\mathrm{ab}} & 2.24 \pm 0.19^{\mathrm{a}} & 2.18 \pm 0.17^{\mathrm{a}} \\ \mathrm{T}_{2} & 1.83 \pm 0.21 \mathrm{~g} & 1.87 \pm 0.17^{\mathrm{fg}} & 1.93 \pm 0.29^{\mathrm{e}-\mathrm{g}} & 1.98 \pm 0.29^{\mathrm{dg}} & 1.91 \pm 0.24^{\mathrm{c}} \\ \mathrm{T}_{3} & 1.99 \pm 0.5 \mathrm{c} \mathrm{d}^{\mathrm{eg}} & 2.04 \pm 0.33^{\mathrm{b}-\mathrm{e}} & 2.08 \pm 0.06^{\mathrm{a}-\mathrm{e}} & 2.12 \pm 0.21^{\mathrm{a}-\mathrm{d}} & 2.07 \pm 0.22^{\mathrm{b}} \\ \text { Mean } & 1.98 \pm 0.25^{\mathrm{c}} & 2.02 \pm 0.20^{\mathrm{bc}} & 2.06 \pm 0.22^{\mathrm{ab}} & 2.11 \pm 0.20^{\mathrm{a}} & \end{array}$

$L S D$ value for treatment and storage $=0.0748 ; L S D$ value for interaction (Treatment $\times$ storage) $=0.2046 ; T_{0}$ : (control) without date pits powder and soy protein isolate; $T_{1}$ : having soy protein isolates; $T_{2}$ : having date pits powder; $T_{3}$ : having date pits powder + soy protein isolates.

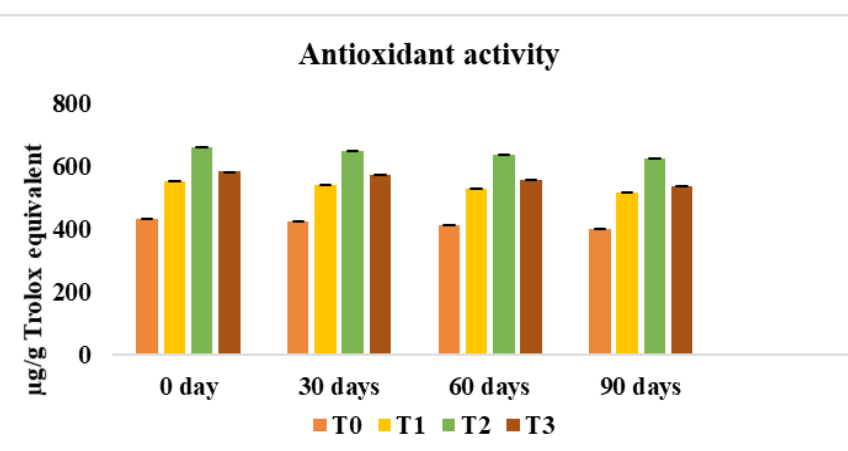

Figure 1: Antioxidant activity ( $\mu g / g$ Trolox equivalent) of date bars.

\section{Total antioxidant activity of date bars}

Antioxidant activity in date bars ranged from 663.09 to $401.86 \mu \mathrm{g} / \mathrm{g}$ Trolox equivalents. Treatment $\mathrm{T}_{2}$ of the date bars showed the maximum antioxidant activity because it has date pit powder in its formulation whereas the minimum antioxidant activity was observed in control treatment $\mathrm{T}_{0}$ (Figure 1). Antioxidant activity in date bars decreased with storage period. Antioxidant activity was found to be highest in date bars treatments at 0 day whereas it was declined during storage and become at lowest level after 90 days storage. Agrahari et al. (2004) conducted research on quality and antioxidant activity of soy enriched apple bar and described that antioxidant activity of soy enriched apple bars decreased during storage period. They found that the soy enriched apple bar had 20-fold of protein and showed 1.6-fold antioxidant activity than the plain apple bar. These findings support our results as antioxidant activity of date bars increased with the incorporation of date pit powder and soy protein isolate, however in storage period at low $(4 \pm 1 \mathrm{C})$ or ambient $\left(22-31^{\circ} \mathrm{C}\right)$ temperatures there was no significant alternations were recorded in total antioxidant and phenols activities (give reference).

\section{DPPH radical scavenging activity of date bars}

The DPPH analysis for the different date bars treatments containing different amounts of soy protein isolate and date pit powder has been given in Figure 2. DPPH free radical scavenging activity in date bars ranged from minimum value in treatment $\mathrm{T}_{0}(551.12$ $\mathrm{mmol} / \mathrm{g}$ ascorbic acid equivalent) to maximum value in treatment $\mathrm{T}_{2}(733.17 \mathrm{mmol} / \mathrm{g}$ ascorbic acid equivalent). DPPH free radical scavenging activity in date bars was decreased with progress in storage time period. It was found to be highest in treatments at 0 day whereas lowest value was observed in treatments after 90 days storage. It is due to the fact that processed products have fast breakdown of phenolic compounds after being exposed to higher temperature for long time (Beh et al., 2012). DPPH 
free radical scavenging activity of apple juice was lower than orange juice during storage (Beh et al., 2012). Results are also in close agreement with Wani et al. (2016) who deliberated about the processing effects on physicochemical and antioxidant properties of apricot (Prunus armeniaca L. variety Narmo) and specified that the maximum DPPH free radical scavenging activity in fresh pulp can be attributed to the richness of the total components of phenolic.

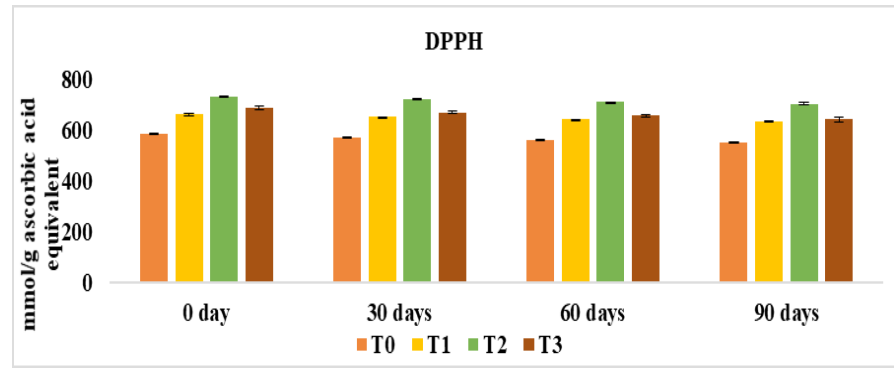

Figure 2: $D P P H$ (mmol/g ascorbic acid equivalent) of date bars.

\section{Total plate count (TPC) of date bar}

The mean values of TPC for treatments ranged from $1.91 \times 10^{4}$ to $2.18 \times 10^{4}$ containing the maximum in $\mathrm{T}_{0}$ and the minimum in $\mathrm{T}_{2}$ (Table 9). These findings demonstrated that TPC gradually increased with the increase in date pit powder concentration in treatment. There was significant impact of storage on TPC of date bars. Within two months storage period at ambient temperature, TPC increased significantly but within acceptable limits, that could be due to decrease in moisture and water activity. The storage means values alter periodically from $1.98 \times 10^{4}$ to $2.11 \times 10^{4}$ at 0 and 90 days respectively. Al-Hooti et al. (1997) described that TPC increased significantly in all four treatments ranging from 1.00 to 2.18 $\log _{10} \mathrm{CFU} / \mathrm{g}$ in date bar samples during six months of storage.

\section{Conclusions and Recommendations}

Results suggested that date pit powder and soy protein isolate enhanced the physicochemical properties of date bars. Combining date pit powder and soy protein isolates increases the antioxidant potential and shelf stability of date bars. Date pit powder and soy protein isolate are decent source of carbohydrates, fiber, minerals and proteins for the production of soy date bars. These date soy bars can be consumed as a ready to eat food, as an appetizer or as a healthy snack food. Date pit powder $r$ can be utilized as functional ingredient in other food products.

\section{Acknowledgements}

The author acknowledged the Higher education commission of Pakistan for providing an opportunity through funding under International Research Support Initiative Program (IRSIP) to carry out part of my $\mathrm{PhD}$ research study abroad.

\section{Novelty Statement}

Fruit bars were prepared using date pit powder to introduce the utilization of waste material in val-ue added product. Date pits are not previously used in food products especially in date fruit bars. Utilization of date pits in fruit bars is an innovative step to boost its consumption.

\section{Author's Contribution}

Lala Rukh: Conceptualization, methodology, analyzed, writing original draft, reviewing and editing were done.

Muhammad Nadeem: Conceptualization, methodology, reviewing, editing and proof reading were done and approved the final manuscript.

Tusneem Kausar: Proof reading done and approved the final manuscript.

Mian Anjum Murtaza: Confirm the availability of all the chemicals and equipments.

Muhammad Luqman: Literature reviewed

Muhammad Bilal Shahid: Performed analysis and calculated the statistical data.

Amal Shaukat: Performed analysis and reviewing.

\section{Conflict of interest}

The authors have declared no conflict of interest.

\section{References}

AACC, 1999. Approved methods of analysis, the American Association of Cereal Chemists, St. Paul, MN.

AACC, 2000. Approved Methods of the American Association of Cereal Chemists, Method, pp. 10-91.

Abbas, S., M.K. Sharif and R. Ejaz. 2016. Preparation of sesame flour supplemented high protein and energy food bars. Biol. Sci. PJSIR., 59(1): 20-32. https://doi.org/10.52763/PJSIR.BIOL. SCI.59.1.2016.20.32

Agrahari, P.R., D.S. Khurdiya, C. Kaur and H.C. 
Kapoor. 2004. Antioxidant activity and quality of soy enriched apple bar. J. Food Process. Preserv., 28(2): 145-159. https://doi. org/10.1111/j.1745-4549.2004.tb00817.x

Al-Hooti, S., J.S. Sidhu., J. Al-Otaibi., H. AlAmeeri and H. Qabazard. 1997. Processing of some important date cultivars grown in United Arab Emirates into chutney and date relish. J. Food Process. Preserv., 21(1): 55-68. https://doi.org/10.1111/j.1745-4549.1997. tb00767.x

Aparecida Damasceno, K., C.A.A. Gonçalves, G.D.S. Pereira, L.L. Costa, P.C.B. Campagnol, P.L. De Almeida and L. Arantes-Pereira. 2016. Development of cereal bars containing pineapple peel flour (Ananas comosus L. Merril). J. Food Qual., 39(5): 417-424. https://doi. org/10.1111/jfq.12222

Bano, S., T. Zahoor and M.A. Sheikh. 2016. Quality assessment of curative and nutritious date fructose biscuit bar. J. Anim. Plant Sci., 26(5): 11-16.

Beh, L.K., Z. Zakaria, B.K. Beh, W.Y. Ho, S.K. Yeap and N.B.M. Alitheen. 2012. Comparison of total phenolic content and antioxidant activities of freeze-dried commercial and fresh fruit juices. J. Med. Plants Res., 6(48): 5857-5862.

Betzelberger, A.M., K.M. Gillespie, J.M. Mcgrath, R.P. Koester, R.L. Nelson and E.A. Ainsworth. 2010. Effects of chronic elevated ozone concentration on antioxidant capacity, photosynthesis and seed yield of 10 soybean cultivars. Plant, Cell Environ., 33(9): 1569-1581. https://doi. org/10.1111/j.1365-3040.2010.02165.x

Bower, J.A. and R. Whitten. 2000. Sensory characteristics and consumer liking for cereal bar snack foods. J., 15(3): 327-345. https://doi. org/10.1111/j.1745-459X.2000.tb00274.x

Chau, C.F., P.C. Cheung and Y.S. Wong. 1997. Functional properties of protein concentrates from three Chinese indigenous legume seeds. J. Agri. Food Chem, 45(7): 2500-2503.

Chen, F.P., B.S. Li and C.H. Tang. 2015. Nanocomplexation between curcumin and soy protein isolate: Influence on curcumin stability/ bioaccessibility and in vitro protein digestibility. J. Agric. Food Chem., 63(13): 3559-3569. https://doi.org/10.1021/acs.jafc.5b00448

Dammak, A., T. Meziou, N. Krid, W. Abdelmaksouda, M. Mseddi, S. Boudaya and H. Turki. 2007. The profile of pustular psoriasis: a report of 34 cases P065. J. Eur. Acad. Dermatol. Venereol., 21(5): 1-10.

Iqbal, M.T. 2003. Effect of different Shortening on the Quality of Cookies. Turk. J. Biol., 30: 87-92.

Kamran, M.M., K. Rauf, Z.N.S. Jamil, Umar and O.M. Tarar. 2008. Processing and shelf life studies of intermediate moisture mango slice. Pak. J. Food Sci.,18: 50-54.

Kurosu, M. 2011. Biologically active molecules from soybeans. Soybean Health, pp. 208-230. https://doi.org/10.5772/18950

Marques, T.R., A.D. Corrêa, A.P. de Carvalho Alves, A.A. Simão, A.C.M. Pinheiro and V. de Oliveira Ramos. 2015. Cereal bars enriched with antioxidant substances and rich in fiber, prepared with flours of acerola residues. J. Food Sci. Technol., 52(8): 5084-5092. https://doi. org/10.1007/s13197-014-1585-2

Munir, M., M. Nadeem, T.M. Qureshi, S. Jabbar, F.A. Atif and X. Zeng. 2016. Effect of protein addition on the physicochemical and sensory properties of fruit bars. J. Food Process. Preserv., 40(3): 559-566. https://doi.org/10.1111/ jfpp. 12635

Munshi, R., A. Kochhar and A. Kaur. 2020. Nutrient selection and optimization to formulate a nutrient bar stable on storage and specific to women at risk of osteoporosis. J. Food Sci. Technol., pp. 1-9. https://doi.org/10.1007/ s13197-020-04343-3

Nadeem, M., F.M. Anjum, M.A. Murtaza and G. Mueen-ud-Din. 2012. Development, characterization, and optimization of protein level in date bars using response surface methodology. Sci. World J., 2012. https://doi. org/10.1100/2012/518702

Ogundele, O.M. 2016. Nutritional and functional properties of soaked and micronized Bambara groundnut seeds and their flours (Doctoral dissertation, University of Pretoria).

Parn, O.J., R. Bhat, T.K. Yeoh and A.A. Al-Hassan. 2015. Development of novel fruit bars by utilizing date paste. Food Biosci., 9: 20-27. https:// doi.org/10.1016/j.fbio.2014.11.002

Pinto, M.D.S., F.M. Lajolo and M.I. Genovese. 2005. Effect of storage temperature and water activity on the content and profile of isoflavones, antioxidant activity, and in vitro protein digestibility of soy protein isolates and defatted soy flours. J. Agric. Food Chem., 53(16): 63406346. https://doi.org/10.1021/jf0502451 
Raza, N., M.U. Arshad, F.M. Anjum, F. Saeed, A.A. Maan and H.B. U1-Ain. 2019. Impact of drying methods on composition and functional properties of date powder procured from different cultivars. Food Sci. Nutr., 7(7): 2345-2352. https://doi.org/10.1002/fsn3.1081

Rendon-Villalobos, R., L.A. Bello-Pérez, P. Osorio-Díaz., J. Tovar and O. Paredes-López. 2002. Effect of storage time on in vitro digestibility and resistant starch content of nixtamal, masa, and tortilla. Cereal Chem., 79(3): 340-344. https:// doi.org/10.1094/CCHEM.2002.79.3.340

Rokhsana, F., R. Yeasmin and A. Nahar. 2007. Studies on the development and storage stability of legume and vegetable-based soup powder. Bangladesh J. Agric. Res., 32(3): 451-459. https://doi.org/10.3329/bjar.v32i3.547

Ryland, D., M. Vaisey-Genser., S.D. Arntfield and L.J. Malcolmson. 2010. Development of a nutritious acceptable snack bar using micronized flaked lentils. Food Res. Int., 43(2): 642-649. https://doi.org/10.1016/j.foodres.2009.07.032

Sirisena, S., K. Ng and S. Ajlouni. 2015. The emerging Australian date palm industry: Date fruit nutritional and bioactive compounds and valuable processing by-products. Compreh. Rev. Food Sci. Food Saf., 14(6): 813-823. https:// doi.org/10.1111/1541-4337.12162

Steel, R.G.D. 1997. Analysis of variance II: multiway classifications. Principles and procedures of statistics: A biometrical approach. pp. 204-252.

Sunita, R. and A.S. Chauhan. 2008. Quality attributes of drum-dried papaya-cereal flakes developed from ripe papaya. Elec. J. Env. Agric. Food Chem., 7(5): 2914-2931.

Szydłowska-Czerniak, A., G. Trokowski., K. Karlovits and E. Szłyk. 2010. Determination of antioxidant capacity, phenolic acids, and fatty acid composition of rapeseed varieties. J. Agric. Food Chem., 58: 7502-7509. https://doi. org/10.1021/jf100852x

Wani, S.M., U. Riyaz, T.A. Wani, M. Ahmad, A. Gani, F.A. Masoodi and S.A. Mir. 2016. Influence of processing on physicochemical and antioxidant properties of apricot (Prunus armeniaca L. variety Narmo). Cogent. Food Agric., 2(1): 1176287. https://doi.org/10.1080/23 311932.2016.1176287

Zineb, G., M. Boukouada, A. Djeridane, M. Saidi and M. Yousfi. 2012. Screening of antioxidant activity and phenolic compounds of various date palm (Phoenix dactylifera) fruits from Algeria. Med. J. Nutr. Metab., 5(2): 119-126. https://doi.org/10.1007/s12349-011-0082-7 